\title{
Transfusjonsmedisin ved et hundreårsmerke
}

\author{
I 1914 disputerte Olav Hanssen på den første norske avhandlingen om et transfusjonsmedisinsk emne. \\ Transfusjon var den gang nesten ukjent som behandlingsmulighet. I 2014 er transfusjon en mangeartet \\ basisaktivitet ved alle somatiske sykehus, avhengig av både frivillige blodgivere og internasjonal mange- \\ milliardindustri. Alternativer til transfusjon er på vei inn, men trolig vil helsetjenesten også i 2114 være \\ avhengig av å kunne transfundere blod-og plasmaprodukter fra blodgivere.
}

Hans Erik Heier

h.e.heier@medisin.uio.no

I 1914 disputerte Olav Hanssen (1878-1965) ved Rikshospitalet på en monografi om transfusjon ved anemi (1) (fig 1). Transfusjon var da et nesten ukjent behandlingsprinsipp i Norge, og kunnskapen om anemiers diagnostikk og patofysiologi var ganske begrenset. Man trodde at tungmetaller kunne stimulere nydannelse av erytrocytter, og ga ofte arsenikk ved kroniske anemier. Hovedspørsmålet for Hanssens arbeid var om transfusjon kunne stimulere til nydannelse av blod, men han var også opptatt av bivirkninger og praktisk gjennomføring av den nye behandlingsformen.

Både friske medarbeidere og enkelte pasienter ble brukt som blodgivere og tappet arterielt. Antikoagulasjonsmidler fantes ikke, så blodet ble defibrinert og filtrert gjennom bomull før transfusjon intravenøst $i$ åpent system (fig 2). Man kjente til at mange pasienter har antistoffer (isoagglutininer) mot andre menneskers erytrocytter, men Hanssen var i tvil om betydningen ved transfusjon. Han refererte ikke til begrepet blodtyper selv om Landsteiner og medarbeidere hadde beskrevet $\mathrm{ABO}$-systemet mer enn ti år tidligere $(2,3)$. Den manglende forståelsen for blodtypenes betydning er tidstypisk. Landsteiner selv var opptatt av om isoagglutininene hadde en rolle i infeksjonsforsvaret, og nevnte i sin artikkel «Über Agglutinationserscheinungen menschlichen Blutes», som han senere ble tildelt nobelprisen for, bare kortfattet at isoagglutininer og blodtyper kunne ha betydning ved transfusjon (2).

Hanssen utførte forlikelighetsprøve, men blod ble gitt enten prøven var negativ eller positiv. Ved positiv prøve fikk pasientene ofte dyspné og ryggsmerter, og det oppsto tegn på hemolyse. Hos én pasient ble det observert hematuri i 14 dager etter transfusjonen. Hanssen konkluderte korrekt med at isoagglutininer som ga positive forlike- lighetsprøver, forårsaket hemolysen. Frysninger og temperaturstigning forekom hyppig, også ved negativ forlikelighetsprøve.

Hanssen fant ingen tegn på at transfusjon kunne stimulere til nydannelse av blod. Han forsto at transfusjon er ren substitusjonsbehandling med tidsbegrenset virkning. Ved kroniske anemier anbefalte han derfor transfusjon bare hvis andre behandlingsformer var uten effekt. Akutt blodtap burde være hovedindikasjon for transfusjon når ikke organismens kompensasjonsmekanismer eller tilførsel av saltvann er tilstrekkelig. Her fulgte han opp von Ott, som allerede i 1883 hevdet at blodtap i stor grad kan erstattes med saltvann (4). Hanssen foreslo også at transfusjon kunne brukes til å stanse blødning ved hemofili.

Avhandlingen førte ikke til gjennombrudd for klinisk transfusjon i Norge. Nødvendig teknologi og organisering lå ennå langt inne i fremtiden. Først i 1948 ble den første norske blodbanken opprettet på Ullevål sykehus (5). Avhandlingens 100årsjubileum er likevel verdt å markere, både fordi den er det første akademiske arbeidet om transfusjon i Norge, og fordi den, tross primitiv teknologi og til dels forvirrende bakgrunnslitteratur, kom til konklusjoner som fortsatt er holdbare.

\section{Transfusjon anno 2014}

Hvert år gis omkring 200000 erytrocyttkonsentrater til mellom 50000 og 60000 pasienter ved norske sykehus $(6,7)$. Flertallet av pasientene er eldre mennesker med anemi på grunn av neoplastiske eller andre kroniske sykdommer (6). I 2012 ble det transfundert 24508 trombocyttkonsentrater (7), de fleste trolig i relasjon til beinmargshemmende cytostatikabehandling. Ved Oslo universitetssykehus fikk 1525 pasienter 8871 trombocyttkonsentrater i 2012 (upubliserte data), og det kan derfor antas at $4000-5000$ pasienter fikk trombocyttkonsentrater på landsbasis. Hvor mange som får plasmaprodukter, er ikke undersøkt, men blødningstilstander og immunologiske sykdommer utgjør trolig de største diagnosegruppene med behov for slik behandling.

På basis av produktprisene ved Blodbanken i Oslo i 2013 kan verdien av produktene fra norske blodbanker anslås til 600-700 millioner kroner per år. Den internasjonale industrien som leverer produkter og tjenester til transfusjon, er en mangemilliardindustri (8). Globalt tappes det over 100 millioner enheter à $450 \mathrm{ml}$ fullblod (9) og fraksjoneres ca. 40000 tonn plasma (G. Zerlauth, Baxter GmbH, personlig meddelelse 2011). Transfusjonstjenesten er blitt en viktig global samfunnsaktør.

Blodbankene dekker behovene som klinikerne definerer, men indikasjon for og resultat av transfusjonen blir ofte ikke tilfredsstillende dokumentert (6). Dette kan tyde på at transfusjon ikke alltid gis med fullgod klinisk gjennomtenkning. Dette er ikke nytt; allerede i 1985 mente Heistø (10)

\section{TRANSFUSION UND ANÄMIE} EINE KLINISCHE STUDIE AUF GRUNDLAGE VON 74 TRANSFUSIONEN BEI 29 FALLEN VON ANAMIE

VON

OLAV HANSSEN

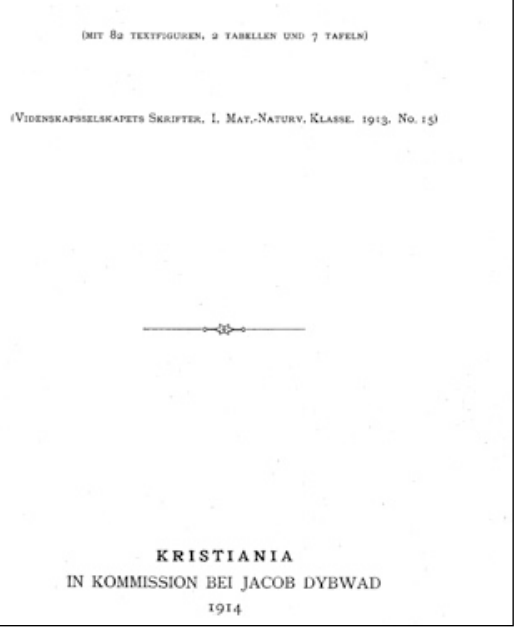

Figur 1 Tittelsiden på Olav Hanssens monografi 


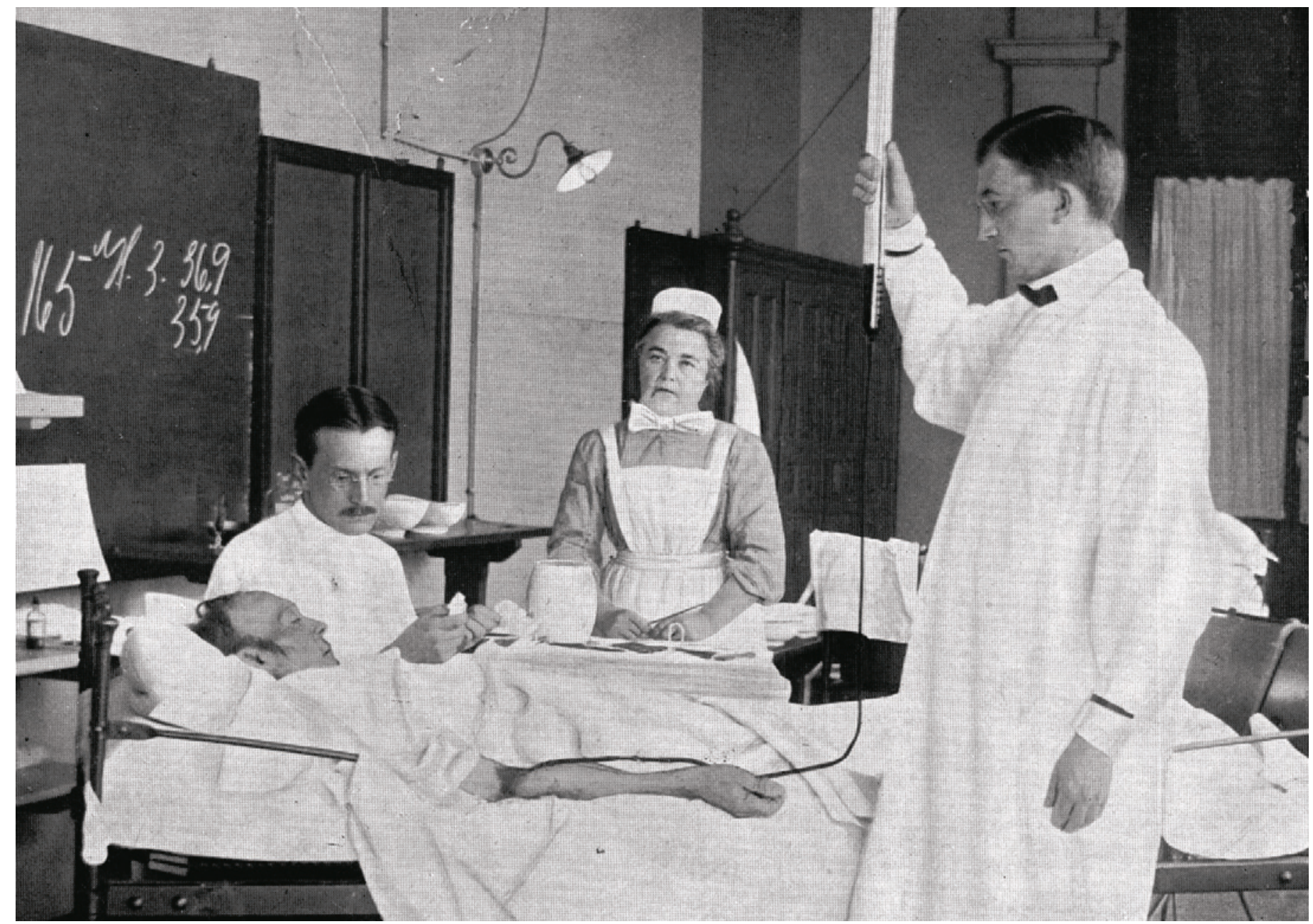

Figur 2 Transfusjon ved Rikshospitalet ca. 1912. Blodet er defibrinert og blir gitt fra målesylinder i åpent system. Bemerk kamferflasken som den ene legen holder klar til bruk ved eventuelle komplikasjoner. Fra Hanssen (1)

at den kliniske anvendelsen av blodprodukter ofte foregikk på sviktende grunnlag.

Antakelsen støttes av at det er påvist betydelige forskjeller i transfusjonspraksis mellom sammenliknbare land og sykehus (11-13). Norge har Nordens laveste forbruk av erytrocytter til transfusjon i forhold til folkemengden, men har lenge ligget over forbruket i for eksempel Nederland, som etter årtusenskiftet dessuten har redusert sitt forbruk med over $20 \%$ (14). I Norge har vedvarende forbruksøkning nå snudd til svak nedgang (7), på tross av økende alder i befolkningen.

Immunglobuliner i høye doser intravenøst (IVIG) kan endre, «modulere», en uønsket immunrespons (15). Slik behandling er forsøkt ved mange vanskelig traktable tilstander. Ved noen tilstander må behandlingen anses etablert, men ofte er den belagt med svak evidens (16). I Norge og andre vestlige land økte forbruket av IVIG sterkt etter årtusenskiftet. I 2009 hadde forbruket nådd et nivå som ikke kunne dekkes fra plasma tappet innenlands. Norges selvforsyningssystem for plasmaprodukter måtte avvikles. I stedet selges nå norsk plasma til europeisk, kommersiell plasmaindustri, som så leverer de ønskede produktene tilbake etter kontrakt med de regionale helseforetakene (17). Her inngår også plasma fra betalte givere.

Norge finnes ca. 100000 frivillige, ubetalte blodgivere (FUB). Disse tilfredsstiller verdens trolig strengeste utvalgskriterier, og sikkerheten for pasientene er meget høy (18). Frivillig, ubetalt blodgivning begynte under den annen verdenskrig i de allierte landene som sivilbefolkningens støtte til kampen for et fritt samfunn (8). Å gi blod frivillig og ubetalt handler om et sosialetisk verdivalg (19). En sekundær begrunnelse er at betalte blodgivere kan være mer utsatt for infeksjoner som kan overføres med blod enn frivillige, ubetalte givere (20), men slike forskjeller er ikke alltid påvist (21). Internasjonale organisasjoner anbefaler medlemslandene å holde seg selvforsynt med blod- og plasmaprodukter ved hjelp av frivillige, ubetalte blodgivere (17), også for å hindre kommersialisering av humant vev (22). Norsk transfusjonstjeneste arbeider for å gjenopprette balansen mellom blodgivning og blodforbruk ved hjelp av FUB (17).

\section{Tilbake til selvforsyning}

En fullblodgivning gir ca. $250 \mathrm{ml}$ plasma. Hvis forbruket av erytrocyttkonsentrater reduseres, kan blodgivere overføres fra fullblodgivning til plasmaferese, der hver givning gir $600 \mathrm{ml}$ plasma. Over tid vil man da kunne gjenopprette balansen mellom produksjon og forbruk, og komme tilbake til nasjonal selvforsyning basert på FUB (17).

Patient blood management (PBM) er et programkonsept for optimalisering av erytrocytt-transfusjon ved elektiv kirurgi. Pasientens egne blodressurser og evne til å tolerere anemi skal styrkes og utnyttes på optimal måte, og transfusjon skal bare gis for å sikre godt behandlingsresultat og 
hindre komplikasjoner. Programkonseptet omfatter tre hovedpunkter: 1) påvisning og behandling av preoperativ anemi, 2) blodsparende kirurgisk og anestesiologisk teknikk, inkludert sikring av evnen til biologisk hemostase og 3) bedring av pasientens evne til å tolerere anemi. PBM-programmer kan gi betydelig innsparing i forbruk av erytrocyttkonsentrater (23-25). Norske anestesiologer aksepterte lavere $\mathrm{Hb}$-verdier som transfusjonsterskel i 2002 enn i 1996. Yngre anestesiologer aksepterte lavere terskel enn eldre (26). PBM-liknende tankegang synes å være på vei inn i norske sykehus og er trolig en del av forklaringen på nedgangen $i$ landets erytrocyttforbruk. PBM-konseptet er også av interesse for håndtering av kroniske anemier og i palliativ sammenheng. Om lag halvparten av erytrocyttforbruket gis på ikke-kirurgiske indikasjoner (6), og velfunderte algoritmer også for slike tilstander vil bidra til å optimalisere transfusjonspraksis.

\section{Utsyn mot 2114}

Det vil alltid forekomme anemier som krever ekstern tilførsel av oksygenbærende substans. Ex vivo-produksjon av blodceller til transfusjon virker for ressurskrevende til rutinemessig bruk (27). Kunstige oksygenbærere vil neppe kunne tjene som annet enn nisjeprodukter (27). Biologisk hemostase blir suboptimal hvis antallet sirkulerende erytrocytter blir lavt, fordi trombocyttene da presses mindre sterkt mot veggen i små arterier (28). Ved beinmargssvikt vil transfusjon av både erytrocytter og trombocytter forbli nødvendig for pasientens overlevelse.

Mulighetene for å manipulere nydannelse av blod vil trolig bedres. Det samme gjelder metoder for å monitorere oksygenering og hemostaseaktivitet, og for å definere behandlingsbehov $(29,30)$. Immunregulerende medikamenter vil overta for mye av forbruket av IVIG. I 2114 vil det fortsatt være behov for blodgiverblod til transfusjon, men forbruket i Norge vil ha gått ned. Forhåpentlig vil balansen mellom norsk blodgivning og forbruk være gjenopprettet og basert på FUB.

Globalt er utfordringene store. For eksempel antar WHO at ca. 800 fødende kvinner dør hver dag (31), og at blødning er årsaken i $25-30 \%$ av tilfellene (32). I 2014 har mange land utilstrekkelig transfusjonstjeneste. I 2114 bør ingen dø som følge av mangel på blod til transfusjon. Da trengs det bevisste politiske og økonomiske reformer i tillegg til god forskning $(31,33)$.

\section{Hans Erik Heier (f. 1944)}

er professor emeritus og tidligere avdelingsoverlege ved Avdeling for immunologi og transfusjonsmedisin, Oslo universitetssykehus. Han har mastergrad i helseadministrasjon fra Universitetet i Oslo. Han har hatt faglige verv nasjonalt og internasjonalt og var president for International Society of Blood Transfusion i perioden 2002-2004.

Forfatter har fylt ut ICMJE-skjemaet og oppgir ingen interessekonflikter.

\section{Litteratur}

1. Hanssen 0. Transfusion und Anämie. Doktoravhandling. Videnskabsselskapets skrifter. I. Mat. Naturv. klasse 1913, nr.15. Kristiania: Jacob Dybwad, 1914

2. Landsteiner K. Über Agglutinationserscheinungen menschlichen Blutes. Wien Klin Wochenschr 1901 46: $1132-4$

3. von Decastello A, Stürli A. Über die Isoagglutinine im Serum gesunder und kranken Menschen. Munch Med Wochenschr 1902: 49: 1090.

4. von Ott D. Über den Einfluss der Kochsalzinfusion auf den verblutenen Organismus im Vergleich mi anderen zur Transfusion verwendeten Flüssigkeiten. Virchows Arch 1883; 93

5. Ørjasæter H, Kornstad L. Det gjelder oss alle. Norges Røde Kors Blodsenter gjennom 50 år. Oslo: Norges Røde Kors, 1983.

6. Heier HE, Nentwich I, Garvik LJ et al. Erytrocytttransfusjon ved Ullevål sykehus. Indikasjoner, forbruk og blodtypeimmunisering. Tidsskr Nor Legeforen 2012; 132: $1742-6$

7. Flesland $\emptyset$, Sjøberg JJ. Blodtransfusjonstjenesten i Norge. Statistikk for 2012. Bærum: Blodbanken Bærum sykehus, Vestre Viken HF, 2013.

8. Starr D. Blood. An epic history of medicine and commerce. New York: Alfred A. Knopf, 1999.

9. WHO. Blood safety and availability. Www. who.int/ mediacentre/factsheets/fs279/en/ (6.8.2014).

10. Heistø H. Det internasjonale og det nasjonale blodmarked. Nytt fra Statens legemiddelkontroll 1985 (3): $1-2$

11. Sirchia G, Giovanetti AM, McClelland DBL et al. Safe and good use of blood in surgery. Use of blood products and artificial colloids in 43 European communities. Luxembourg: Office for Officia Publications of the European Communities, 1994.

12. Heier HE. Produksjon og forbruk av blodprodukter i Norge. Tidsskr Nor Lægeforen 1993; 113: 18-22.

13. Hasley PB, Lave JR, Hanusa BH et al. Variation in the use of red blood cell transfusions. A study of four common medical and surgical conditions. Med Care 1995: 33: 1145-60.

14. Borkent-Raven BA, Janssen MP, Van Der Poel CL. Demographic changes and predicting blood supply and demand in the Netherlands. Transfusion 2010 50: $2455-60$.

15. Nydegger UE. Immunoglobulins. I: Simon TL, Snyder EL, Solheim BG et al., red. Rossi's prin- ciples of transfusion medicine. Hoboken, NJ: Wiley-Blackwell 2009: 260-72.

16. Kornør H, Hammerstrøm KT, Brurberg KG et al. Immunmodulerende behandling med intravenøst gammaglobulin. Rapport nr. 14-2008. Oslo: Kunnskapssenteret, 2008. www.kunnskapssenteret.no/ Publikasjoner (6.8.2014).

17. Heier HE, Olaussen RW, Svenningsen VM. Går det mot blodforsyningskrise i Norge? Tidsskr Nor Legeforen 2012; 132: 2508-10.

18. Steinsvåg CT, Espinosa A, Flesland $\emptyset$. Eight years with haemovigilance in Norway. What have we learnt? Transfus Apheresis Sci 2013; 49: 548-52.

19. Titmuss RM. The gift relationship. From human blood to social policy. Expanded and updated version. New York: New Press, 1997.

20. Beal RW, van Aken WG. Gift or good? A contemporary examination of the voluntary and commercial aspects of blood donation. Vox Sang 1992; 63: 1-5.

21. Eastlund T. Monetary blood donation incentives and the risk of transfusion-transmitted infection. Transfusion 1998; 38: 874-82.

22. Convention for the protection of human rights and dignity of the human being with regard to the application of biology and medicine: Convention on human rights and biomedicine.

http://conventions.coe.int/Treaty/en/Treaties/ $\mathrm{Html} / 164 . \mathrm{htm}$ (6.8.2014)

23. Hofmann A, Farmer S, Towler SC. Strategies to preempt and reduce the use of blood products: an Australian perspective. Curr Opin Anaesthesiol 2012; 25: 66-73.

24. Spahn DR, Goodnough LT. Alternatives to blood transfusion. Lancet 2013; 381: 1855-65.

25. Isbister JP. The three-pillar matrix of patient blood management-an overview. Best Pract Res Clin Anaesthesiol 2013; 27: 69-84

26. Reine PA, Kongsgaard UE, Smith-Erichsen N. Hemoglobingrenser og transfusjonspraksis blant norske anestesiologer. Tidsskr Nor Lægeforen 2004: 124: 2610-2

27. Klein HG, Anstee DJ. Alternatives to allogeneic transfusion. I: Klein HG, Anstee DJ. Mollison's blood transfusion in clinical medicine. Hoboken, NJ: Wiley Blackwell, 2014: 827-31.

28. Turitto VT, Hall CL. Mechanical factors affecting hemostasis and thrombosis. Thromb Res 1998; 92 (suppl 2): S25-31.

29. Johansson PI, Ostrowski SR, Secher NH. Management of major blood loss: an update. Acta Anaesthesiol Scand 2010; 54: 1039-49.

30. Hagemo JS, Næss PA, Johansson P et al. Evalu-

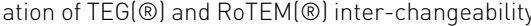
in trauma patients. Injury 2013; 44: 600-5.

31. Maternal mortality. Fact sheet nr. 348. Genève: World Health Organization, 2012. www.who.int/ mediacentre/factsheets/fs348/en (6.8.2014).

32. Walfish M, Neuman A, Wlody D. Maternal haemorrhage. Br J Anaesth 2009; 103 (suppl 1): i47-56.

33. Heier HE. Blod og samfunn. Streiftog med refleksjoner i transfusjonstjenestens historie. Rapport 2000: 1 Oslo: Senter for helseadministrasjon, Det medisinske fakultet, Universitetet i Oslo, 2000.

Mottatt 23.3. 2014, første revisjon innsendt 11.6. 2014, godkjent 9.7. 2014. Redaktør: Hanne Støre Valeur. 